\author{
Marta Studenna-Skrukwa
}

https://orcid.org/0000-0002-6197-543X

(Poznań)

\title{
MIĘDZY UTOPIĄ SOCJALIZMU A KARYKATURĄ ZACHODU. NIE-DZIECIĘCA INTERPRETACJA ŚWIATA PRZEDSTAWIONEGO W TRYLOGII O SKRZACIE NIEUMIAŁKU NIKOŁAJA NOSOWA
}

\section{Abstract}

This paper attempts an interpretation of Nikolai Nosov's novels about the adventures of Dunno, which enjoyed a cult status in the Soviet Union. Despite being children's literature, they are examined in terms of themes that have little to do with young readers. The analysis is historical rather than literary, aiming chiefly to elucidate the cultural context and the social notions from the period of Khrushchev's thaw. Here, the author undertakes to answer the questions concerning the extent to which the reality created by Nosov served to mould the socialist worldview as early as childhood and, simultaneously, whether it incidentally offered the adult reader an opportunity of intellectual escape into the officially condemned world.

\section{Key words}

Soviet Union, daily life, Soviet children's literature, Dunno, Sun City, space in culture 


\section{TWÓRCZOŚĆ NIKOŁAJA NOSOWA W KANONIE RADZIECKIEJ LITERATURY DZIECIĘCEJ}

Literatura dziecięca odgrywała $\mathrm{w}$ propagandzie radzieckiej newralgiczną rolę. Jej znaczenie polegało na docieraniu do bardzo młodych umysłów oraz dostarczaniu wskazówek do wychowania „nowego człowieka”, dla którego główną wartością pozostawałby interes państwa. Pisze się wręcz, że była narzędziem "upaństwawiającym dzieciństwo". Jednocześnie specyfika świata przedstawionego dawała utalentowanym autorom możliwości przepuszczania treści swobodniejszych interpretacyjnie. Przykładem utworu zawierającego czytelne dla dorosłego odbiorcy satyryczne drugie dno jest kultowy cykl powieści Nikołaja Nosowa o przygodach skrzata Nieumiałka².

Nikołaj Nosow urodził się w 1908 roku w Kijowie. Przez około dwadzieścia lat pracował jako reżyser filmów popularno-naukowych i instruktażowych. Literacko debiutował w 1938 roku na łamach pisma „Murziłka”. W 1952 roku nagrodzono go Nagrodą Stalinowską za powieść „Witia Malejew w szkole i domu". Największą popularność przyniosła mu jednak trylogia o Nieumiałku, za którą w 1969 roku odebrał Państwową Nagrodę im. Nadieżdy Krupskiej. Zmarł w Moskwie w 1976 roku. Pozostaje jednym z najbardziej poczytnych (przygody Nieumiałka przetłumaczono na wiele języków, w tym na japoński) i wspominanych $\mathrm{z}$ największym sentymentem dziecięcych pisarzy radzieckich ${ }^{3}$.

\footnotetext{
${ }^{1}$ Voskobojnikov 2012, s. 76-88.

${ }^{2}$ Pierwsza część trylogii, pierwotnie ukazywała się na łamach ukraińskiego miesięcznika „Barwinok” w 1. 1953-1954 pt. „Przygody Nieumiałka i jego towarzyszy”. W 1954 roku pojawiła się jako publikacja książkowa zatytułowana „Przygody Nieumiałka i jego przyjaciół”. W Polsce, po raz pierwszy ukazała się w miesięczniku „Literatura Radziecka” w 1956 roku pod tytułem „Przygody Niewiedzka i jego przyjaciół” w tłumaczeniu Marii Dolińskiej. Karzełki są tu nazywane „tyciuchami”. Pierwsze polskie wydanie książkowe pojawiło się w 1957 roku w tłumaczeniu Janiny Lewandowskiej. Część druga, zatytułowana „Nieumiałek w Słonecznym Mieście”, była drukowana w 1958 roku w czasopiśmie „Junost”" i w tym samym roku ukazała się jako książka. W Polsce na łamach „Literatury Radzieckiej” w 1959 roku ukazało się tłumaczenie Marii Dolińskiej „Niewiedzek w Słonecznogrodzie”, natomiast książka w tłumaczeniu Janiny Lewandowskiej pojawiła się w 1962 roku. Część trzecia - „Nieumiałek na Księżycu” wychodziła na łamach czasopisma „Siem’ja i szkoła” w l. 1964-1965. W 1965 roku wydana w formie książki. Nie została przetłumaczona na język polski. W ZSRR i po jego rozpadzie trylogia była wielokrotnie wznawiana przez różne oficyny. Pierwszymi ilustratorami części pierwszej i drugiej zostali ukraińscy twórcy: Kira i Wiktor Grigoriewowie, choć to Aleksiejowi Łaptiewowi bohaterowie zawdzięczają swoje najbardziej rozpoznawalne wizerunki. Ilustratorem pierwszego wydania trzeciej części został Gienrich Walk. W niniejszym tekście korzystałam z następujących wydań: Nosow 1984 (wydanie radzieckiej oficyny „Raduga” dla polskiego czytelnika); Nosow 1962; Nosov 1988.

${ }^{3}$ Biografiâ Nikolaâ Nosova 2013; Kazûl'kina 2001, Tveritina 2014. Jest pewną ironią losu, że za najbardziej przepełnioną elementami fantastyki powieść przyznano Nosowowi nagrodę im. Krup-
} 
W trylogii o Nieumiałku Nosow po mistrzowsku łączy dwa zadania. Po pierwsze, pozostaje wierny priorytetowi radzieckiej literatury dziecięcej, jakim był dydaktyzm z jego funkcją skrupulatnego wyjaśniania, „co to znaczy dobrze i co to znaczy źle" . Realizuje też zasadę Maksyma Gorkiego, według której „nie powinno być jaskrawej różnicy między utworem beletrystycznym

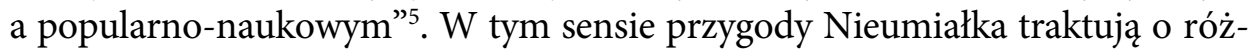
nych typach ustrojów polityczno-społecznych, które zostają poddane krytyce efektywności i ocenie moralnej. Dobro i zło są bardzo konkretnie zdefiniowane, a jednocześnie styl Nosowa pozostaje wolny od moralizatorskiego tonu i zapewne to przesądza o sukcesie trylogii. Po drugie, fundamentalne wartości ilustrowane są przykładami na tyle sugestywnymi dla dorosłego odbiorcy, że nie sposób „nie słyszeć” pytania o granice propagandy ${ }^{6}$.

\section{ŚWIAT NIEUMIAŁKA: POZA CZASEM I PRZESTRZENIĄ, ALE JAKBY W ZSRR}

Pierwsza część - „Przygody Nieumiałka i jego przyjaciół” - wprowadza czytelnika do Kwiatowego Miasta: krainy karzełków, w której odnajdziemy sporo odwołań do radzieckich realiów lat pięćdziesiątych i sześćdziesiątych

skiej, która w swoim podejściu pedagogicznym fantastyki kompletnie nie tolerowała. Zob. Sudilowskij 2000.

${ }^{4}$ Taki tytuł nosi wydany w latach dwudziestych XX wieku zbiór wierszy dla dzieci autorstwa Włodzimierza Majakowskiego. Szerzej patrz: Cjurpa 1957, s. 116-122; Marszak 1952, s. 134-140; Marszak 1958, s. 169-173.

${ }^{5}$ Marszak 1958, s. 170.

${ }^{6} \mathrm{~W}$ podobnej konwencji została napisana, znana polskiemu czytelnikowi, pierwsza część trylogii dziecięcej o przygodach profesora Baltazara Gąbki autorstwa Stanisława Pagaczewskiego. Cały cykl tworzą utwory „Porwanie Baltazara Gąbki” (1965), „Misja Profesora Gąbki” (1975) oraz „Gąbka i latające talerze” (2002). Czytelna dla dorosłego odbiorcy druga warstwa narracji jest najbardziej zauważalna w pierwszej powieści. Część akcji toczy się w Krainie Deszczowców, rządzonej przez tyrana, który swoją władzę opiera na aparacie szpiegowskim i polityce zastraszania. Porywa on profesora Gąbkę - wielkiej sławy biologa, i próbuje nakłonić go do współpracy przy wyhodowaniu ogromnych żab dla celów militarnych. Jest to oczywiste nawiązanie do totalitaryzmu i być może echo orwellowskich inspiracji. Popularność serii $w$ PRL-u wynikała $z$ tych samych przesłanek, z jakich popularność Nosowa w ZSRR: braku moralizatorskiego tonu i dystansu wobec mędrkowatości, które pozwalały dzieciom „przeżyć przygodę czytania”. Podobne w obu krajach mechanizmy cenzury umożliwiały wmontowanie w narrację przesłania dla dorosłych: „(...) cenzura PRL hołdowała przekonaniu, że wiele $\mathrm{z}$ treści, a zwłaszcza $\mathrm{z}$ podtekstów, nie zostanie przez dzieci zrozumiane, a dorośli i tak książek dla dzieci nie czytają. Większą wagę przywiązywano np. do tego, by w opisach wiejskich pejzaży nie pojawił się kościól, a w wiejskich chatach - dewocjonalia, niż do treści ezopowych. W związku z tym to i owo można było przemycić". Pisarz z Krainy Deszczowców, 2016. 
XX wieku. Początkowo główny bohater daje się poznać jako najmniej sympatyczna postać: w przeciwieństwie do swoich kolegów niczego konkretnego nie potrafi, nieustannie się przechwala, jest raczej tchórzliwy i pogardliwy wobec innych. Również wygląd zewnętrzny wyróżnia Nieumiałka:

Ów Nieumiałek nosił jaskrawoniebieski kapelusz, żółte kanarkowe spodnie i pomarańczową koszulę z zielonym krawatem. W ogóle Nieumiałek przepadał za jaskrawymi barwami. Wystrojony niczym papuga, całymi dniami wałęsał się po mieście, wymyślał niestworzone historie i opowiadał je wszystkim

Oś fabuły stanowi wyprawa balonem skonstruowanym przez najmądrzejszego karzełka w Kwiatowym Mieście - Umiałka. W jej wyniku ludkowie trafiają do Zielonego Miasta i Latawcowa. W pierwszej miejscowości mieszkają doskonale zorganizowane i pracowite dziewczynki, które podejmują się opieki nad balonowymi rozbitkami. W drugiej żyją wyłącznie chłopcy, którzy zajmują się głównie przyjemnościami: latem kąpią się i opalają na plaży, zimą jeżdżą na łyżwach, a przede wszystkim i bez względu na porę roku puszczają latawce. Różnice charakterologiczne, tj. zamiłowanie do pracy dziewczynek i hedonizm chłopców, stanowiły główną przyczynę, dla której ci ostatni wyprowadzili się i założyli odrębną osadę. Niespodziewane pojawienie się przybyszów z Kwiatowego Miasta i związane z tym zamieszanie wybijają z rytmu codzienności zarówno całe Zielone Miasto, jak i Latawcowo oraz wymuszają wznowienie wzajemnych kontaktów.

Społeczności karzełków żyją raczej beztrosko, choć nie są wolne od proble$\mathrm{mu}$ niedoboru towarowego, stanowiącego bez wątpienia jedną z podstawowych bolączek życia codziennego w ZSRR. Motyw ten pojawia się w rozmowie dwóch mieszkanek Zielonego Miasta:

- Co za okropny kapelusz! Co go włożę - ciągle źle! Miałam zamiar zrobić sobie
kapelusz z szerokim rondem, ale nie starczyło materiału i musiałam zrobić z ma-
łym, a przy małym rondzie twarz wydaje się okrągła, a to wcale nie jest ładne ${ }^{8}$.

W tle niezwykłych przygód, osadzonych w całkiem przyjemnym otoczeniu, pobrzmiewają typowe radzieckie niedogodności lokalowe. Nieumiałek

\footnotetext{
${ }^{7}$ Nosow 1984, s. 8. Wygląd i hedonistyczna postawa Nieumiałka to najprawdopodobniej aluzja na temat stilagów - pierwszej radzieckiej subkultury. Stiladzy pojawili się pod koniec lat 40 . XX wieku na ulicach wielkich miast ZSRR. Stanowili odłam szerszego europejskiego zjawiska, tzw. Pokolenia '52 (do którego zaliczają się też francuscy zazous, brytyjscy teddy boys, rumuńscy malagambiści, czechosłowaccy potàpka, polscy bikiniarze), tj. fali subkultur młodzieżowych fascynujących się amerykańskim stylem życia. Wspólnym mianownikiem była dla nich kontestacja otaczającej rzeczywistości głównie przez ekstrawagancki ubiór i obojętność wobec linii politycznej swoich państw. W przypadku stilagów oznaczało to bojkot haseł mobilizujących do budowy komunizmu, a w praktyce: „ostentacyjne, publiczne nic nierobienie”. Patrz szerz.: Kozlov 2015; Chłopek 2005, s. 38.

${ }^{8}$ Nosow 1984, s. 62.
} 
i jego przyjaciele w szesnastu zamieszkują jeden dom, i choć nie jest powiedziane, jak ten dom dokładnie wygląda, niemal naturalnie kojarzy się z wielorodzinną komunałką. Nawet w nowoczesnym i bardzo funkcjonalnym Zielonym Mieście z własnym wodociągiem, zapewniającym stały dostęp do bieżącej wody, nikogo nie dziwi niski standard mieszkalnictwa:

Niezabudka zaprowadziła Nieumiałka do kuchni, gdzie znajdowała się umywalka. Obok wisiał ręcznik, a na półeczce leżało mydło i pasta do zębów9.

Mimo różnic charakterologicznych i pewnych odmienności obyczajowych mieszkańcy wszystkich opisywanych miejscowości należą do „jednego świata": żyją podobnie i hołdują tym samym wartościom. Nikt nie jest wyraźnie obcy, nikomu też nie zagraża trwałe wykluczenie ze wspólnoty. Napięcia $\mathrm{w}$ relacjach międzyosobowych regulowane są przez formy zbliżone do publicznej samokrytyki. Podobną rolę spełnia mechanizm potępiania złych zachowań na forum grupy. Gdy oszustwa Nieumiałka zostają zdemaskowane i przyjaciele bezlitośnie z niego szydzą, mieszkanki Zielonego Miasta widzą sprawę znacznie szerzej:

\footnotetext{
- Wstyd, chłopcy! - zawołała Niezabudka. - Dlaczego się z niego wyśmiewacie?

- To po co nas oszukiwał? - odpowiedział Pączek.

- Czy on was oszukiwał? - zdziwiła się Niezabudka. - Oszukiwał nas, a wyście milczeli, a więc byliście jego wspólnikami!

- W niczym nie jesteście lepsi od niego! - krzyknęła Śnieżyczka. - Przecież wiedzieliście, że on kłamie i przechwala się, a żaden $\mathrm{z}$ was go nie powstrzymał. Żaden $\mathrm{z}$ Was mu nie powiedział, że to źle. W czym jesteście lepsi?

- Wcale nie mówimy, że jesteśmy lepsi! - wzruszył ramionami Pączek.

- No to nie drwijcie z niego, jeżeli sami nie jesteście lepsi! - wtrąciła do rozmowy Octusia. - Inni na waszym miejscu już dawno pomogliby mu się poprawić!

Pączek i Cukierek zawstydzili się i zaprzestali drwin ${ }^{10}$.
}

Wyraźne jest tu nawiązanie do obecnego w radzieckim dyskursie propagandowym motywu współodpowiedzialności każdej jednostki za kondycję społeczeństwa. Nie wystarczy samemu być dobrym, trzeba jeszcze pomagać innym stawać się lepszymi - taka postawa miała charakteryzować dobrego kierownika zmiany, zaangażowanego komsomolca czy wzorowego pracownika.

Charakterystycznymi cechami radzieckiej rzeczywistości w okresie od zakończenia II wojny światowej do pierestrojki były kult nauki i pochwała szeroko pojętej wynalazczości. Umiałek zawdzięcza swoją pozycję lidera posiadanej wiedzy, którą czerpie z książek.

\footnotetext{
${ }^{9}$ Ibidem, s. 70.

${ }^{10}$ Ibidem, s. 159.
} 
W jego pokoju książki leżały na stole, pod stołem, na łóżku i pod łóżkiem. Nie było miejsca, gdzieby nie leżały. Z tego czytania Umiałek stał się bardzo mądry, toteż wszyscy go słuchali i bardzo lubili. Nosił czarne ubranie, a gdy siadał przy stole i wkładał na nos okulary, by poczytać książkę - wyglądał zupełnie jak jaki profesor ${ }^{11}$.

Bohaterowie Nosowa lubują się w wielofunkcyjnych udogodnieniach. W powieści pojawiają się m.in.: samochód napędzany wodą sodową z sokiem wyposażony w rurkę, która umożliwiała picie napoju w trakcie jazdy; rurociąg trzcinowy oraz meble wysuwane ze ściany ${ }^{12}$. Ludkowie operują pojęciami takimi jak mechanizacja i racjonalizacja pracy. Nie zabrakło motywu hodowania nowych gatunków roślin, co znamionowało radziecką politykę rolną w epoce Stalina i Chruszczowa ${ }^{13}$. Na autorytet nauki powołuje się Umiałek przy wyznaczaniu granic racjonalności w świecie skrzatów: „Nauka nie wspomina o istnieniu stugłowych smoków (...). Znaczy to, że ich nie ma"14. I wreszcie, wieńcząca pierwszą część trylogii, metamorfoza Nieumiałka przejawia się w dobrowolnym doskonaleniu umiejętności czytania i pisania.

${ }^{11}$ Ibidem, s. 7. Z kultem nauki wiązało się otaczanie akademików społecznym szacunkiem. Po doktoracie pracownik naukowy zarabiał ok. dwukrotnie więcej niż praktykujący lekarz. Praca naukowa nie była tak prestiżowa jak dyplomaty, ani tak pożądana jak kierownika sklepu (ze względu na dostęp do asortymentu towarów), ale na pewno cieszyła się ogromnym poważaniem. Delwig 2011, s. 117-118.

${ }^{12}$ Wątek praktycznej wynalazczości można potraktować jako antecedencję trendu modernizacji życia codziennego charakteryzującego epokę Leonida Breżniewa (1964-1982). W ówczesnym dyskursie prasowym znajdziemy liczne przykłady nowinek (architektonicznych, mechanicznych, w zakresie AGD itp.), proponowanych radzieckiemu człowiekowi w ramach kolejnych pięciolatek. Część z tych innowacji wydaje się tak bardzo dziwna, że pozwala wątpić nie tylko w to, czy kiedykolwiek zostały wprowadzone w życie, ale też w sens ich funkcjonalności. Np. mieszkania w dwu, budowanych w 1966 roku, szesnastopiętrowych blokach w moskiewskiej dzielnicy Nowyje Czeriomuszki miały być wyposażone w lampy przesuwane po powierzchni sufitu tak, aby można było przyciągać je do miejsca, w którym w danym momencie potrzebne jest oświetlenie. Zob. Dom novogo byta 1966.

${ }^{13}$ Eksperymenty w zakresie rolnictwa położyły największy cień na sukcesach radzieckiej nauki. Rewelacje dostarczane przez inspirowaną neolamarkizmem „nową biologię” (zwaną też „twórczym radzieckim darwinizmem”) Iwana Miczurina i Trofima Łysenki były zdominowane wolą nieograniczonego przekształcania praw rządzących naturą. Odrzucanie istnienia genów, twierdzenie o dziedziczeniu cech nabytych z zewnątrz i możliwości przekształcania jednych gatunków w drugie oraz samorództwie z martwej materii nieorganicznej składały się na przekonanie o pełnej plastyczności świata biologicznego. Łysenkizm wyposażał człowieka w demiurgiczną moc, co doskonale wpisywało się w klimat stalinowskiego woluntaryzmu. Popularność łysenkizmu w ZSRR wynikała ze skonkretyzowanej obietnicy, jaką przedkładał: dzięki możliwościom dostosowywania cech gatunkowych roślin uprawnych do warunków zewnętrznych „nowa radziecka biologia” w szybkim tempie rozwiąże problem niedoboru żywności. Odpowiadał też filozoficznym fundamentom marksizmu: Łysenko zakładał, że o przetrwanie gatunku walczą nie poszczególne osobniki (stąd krytyka darwinowskiego indywidualizmu), ale gatunek jako kolektywna całość. Wreszcie, spektakularna „naukowa” kariera Łysenki uderzała w autorytet „reakcyjnych” uczonych. Patrz szerz.: Amsterdamski 1981; Gould 1999, s. 143-161; Köhler 2013.

${ }^{14}$ Nosow 1984, s. 148. 
Bezpośrednie echa czasów stalinowskich odnajdzie czytelnik w epizodzie pisarza Sprytkiewicza. Ów niespełniony literat wykorzystuje w poszukiwaniu weny twórczej wątpliwe pod względem moralnym urządzenie o tajemniczej nazwie mamrotograf. Niepozorna walizeczka umożliwia założenie podsłuchu $\mathrm{w}$ dowolnym mieszkaniu i czerpanie inspiracji „że tak powiem $\mathrm{z}$ natury”. $\mathrm{Z}$ pewnością dla wielu dorosłych odbiorców humor jest tu raczej czarny.

- Ale czy każdy się zgadza, żeby do jego mieszkania wstawić mamrotograf? zauważył Śrubka.

- O, ja to robię bardzo sprytnie! - odrzekł Sprytkiewicz. - Przychodzę na przykład do kogoś z wizytą i biorę ze sobą mamrotograf, który jak sami widzicie, jest podobny do walizki. Wychodząc, niby to zapominam mojej walizki pod stołem lub krzesłem, potem zaś słyszę, o czy mówią gospodarze, gdy mnie nie $\mathrm{ma}^{15}$.

Kluczowa dla „Przygód Nieumiałka” wyprawa balonem z jednej strony odwołuje się do uniwersalnego w literaturze motywu podróży, a szczególnie do motywu lotu balonem charakterystycznego dla powieści Juliusza Verne’a. Z drugiej, można przypisać jej „lokalny” radziecki wymiar, w którym stanowiłaby nawiązanie do propagowanej od lat trzydziestych XX wieku fascynacji lotnictwem $^{16}$. Balonowa eskapada odnosi się też do programu kosmicznego. Zarówno jej początkowi, jak i powrotowi śmiałków towarzyszy patos słowny przypominający późniejsze doniesienia prasowe o sukcesach radzieckiej kosmonautyki.

Ogromny balon parą nadęty,

Odleciał właśnie w niebios odmęty.

Nasze karzełki chociaż nie ptacy,

Za to lotnicy nie byle jacy!

I wrota wiedzy dla nas otwarte,

Już dziejów nowych odwracamy kartę! ${ }^{17}$

\footnotetext{
${ }^{15}$ Ibidem, s. 113.

${ }^{16}$ Rozwój lotnictwa stanowił jeden z priorytetów polityki gospodarczej ZSRR w latach trzydziestych XX wieku. Pionierskie przeloty dokonywane przez lotników radzieckich wzbudzały zainteresowanie na całym świecie. W 1936 roku W.P. Czkałow, A. W. Bieliakow i G.F. Bajdukow na pokładzie samolotu ANT-25 przelecieli bez lądowania ponad 9000 kilometrów, z Moskwy nad arktycznymi terenami ZSRR do wyspy Udd na Morzu Ochockim, nazwanej potem wyspą Czkałowa. Rok później ta sama załoga przeleciała z Moskwy nad Biegunem Północnym do Vancouver w stanie Waszyngton. Oba te przeloty nosiły propagandowe hasło „Stalinskij Marszrut”, a Walerij Czkałow stał się bohaterem, którego kult był porównywalny z późniejszym kultem Gagarina. Bajkowy lot balonem asocjuje się wprost $\mathrm{z}$ wyczynem radzieckiej załogi pod dowództwem Pawła Fedosenki, która w 1934 roku wzniosła się balonem Osoaviakhim-1 na wysokość 20, 500 metrów, co stanowiło ówczesny rekord świata. Po osiągnięciu założonego pułapu Fedosenko podjął ryzykowaną decyzję o dalszym wznoszeniu, ale wkrótce stracił panowanie nad balonem i cała załoga tragicznie zginęła. Zob. Schier 1982, s. 76-79; Zaloga 2003, s. 8; O’Mahony 2017, s. 35-52.

${ }^{17}$ Nosow 1984, s. 48.
} 


\section{SŁONECZNE MIASTO, CZYLI KOMUNISTYCZNY RAJ}

Podróż pozostaje lejtmotywem także drugiej części trylogii zatytułowanej „Nieumiałek w Słonecznym Mieście”. Tym razem, główny bohater i dwójka nowych postaci, Pstrokatek i Hafteczka, wyprawiają się samochodem przed siebie i trafiają do tytułowego Słonecznego Miasta. Pobyt w nim owocuje serią niesamowitych przygód, jednak dorosłemu czytelnikowi zdecydowanie ciekawsze wyda się tło, w których zostały osadzone. W Słonecznym Mieście materializuje się bowiem wizja idealnej metropolii ze wszystkimi udogodnieniami mającymi służyć radzieckiemu człowiekowi ${ }^{18}$. Co istotne, nie dzieje się to za sprawą uwarunkowań magicznych, ale wynika z postępu technologicznego. Wszystkie innowacje bytowe stanowią rezultat myśli naukowo-inżynieryjnej, a ich budowa i działanie opisywane są na tyle szczegółowo, że doskonale popularyzują fizykę, chemię i mechanikę na poziomie szkoły podstawowej. Spójność realiów Słonecznego Miasta z założeniami radzieckiej modernizacji II poł. XX wieku jest wyraźna: opisywane nowinki techniczne albo realnie funkcjonowały w dużych miastach ZSRR, albo propagowano ich wdrożenie. W wielu przypadkach dostarczyły natomiast niezwykle udanych przykładów fantastyki naukowej.

Słoneczne Miasto zawdzięcza swoją nazwę warunkom atmosferycznym: w dzień jest zawsze ładna pogoda, świeci słońce, a chmury rozpylane są specjalnym proszkiem. Deszcz wywołuje się innym specyfikiem i tylko w miejscach, w których go potrzeba (ogrody, sady), w samym mieście rzadko i ewentualnie $\mathrm{w}$ nocy ${ }^{19}$. Ta regulacja pogodowa, stosowana w Moskwie od czasów radzieckich, jest praktykowana do dziś, mimo kosztów, jakie za sobą pociąga. Chmury znad stolicy Rosji usuwa się przede wszystkim w Dzień Zwycięstwa (9 maja), Święto Pracy (1 Maja) czy urodziny Władimira Putina (7 października) ${ }^{20}$.

Przedpola Słonecznego Miasta zostały w pełni zagospodarowane pod uprawy: pracują na nich automatyczne kombajny, które orzą, sieją, bronują, użyźniają glebę i niszczą chwasty. Dzięki urządzeniom sterowym zadania te wykonywane są bez udziału maszynisty. Pełna mechanizacja pracy pozwala na trzykrotny zbiór plonów w ciągu lata. Niewątpliwie taka wizja rolnictwa wypływała $\mathrm{z}$ radzieckich założeń gospodarczych: wieś miała przede wszyst-

\footnotetext{
${ }^{18}$ Asocjacja z „Miastem Słońca” Tomasza Campanelli wydaje się w tym miejscu nadto oczywista.

${ }^{19}$ Nosow 1962, s. 36.

${ }^{20}$ Radziwinowicz 2017.
} 
kim służyć zaopatrzeniu miasta, a jej dziedzictwo kulturowe nie podlegało żadnej ochronie ze strony instytucji państwa ${ }^{21}$.

Samo Słoneczne Miasto jest doskonale zurbanizowane. Po szerokich arteriach poruszają się rozmaite pojazdy: autokoniki, autospirale, reaktywne trąboloty (transport indywidualny) 22 . Do użytku mieszkańców pozostaje też, promowany zresztą, transport publiczny, na który składają się autobusy i taksówki automatyczne (bez szofera, z programatorami trasy). Transport ten jest efektywny (nie ma spóźnień, awarii technicznych, korków, nie istnieje problem niekorzystnych warunków atmosferycznych), i komfortowy. Przywołanie dostępności rozrywek na pokładzie autobusu przywołuje natomiast na myśl wyobrażenie o komforcie podróży dalekodystansowych, a w szczególności lotniczych.

Drzwi otworzyły się gościnnie, cała trójka wsiadła i autobus potoczył się dalej. Przy każdym oknie znajdował się mały stolik, a po obu jego stronach miękkie kanapki. Na stolikach leżały gazety, pisma, a nawet szachy, warcaby, domino i różne inne gry. Ściany między oknami zdobiły ładne obrazki, a u sufitu zwisały barwne choragiewki, nadając całemu autobusowi wesoły wygląd. W przedniej części wozu ustawiony był telewizor i kto miał ochotę - mógł ogląać różne filmy, mecze piłki nożnej oraz inne programy telewizji. I wreszcie w tyle wozu była strzelnica. (...) w autobusie nie było konduktora, a tylko na ścianie wisiał głośnik, oznajmiający głośno nazwy przystanków ${ }^{23}$.

Gastronomia w Słonecznym Mieście zorganizowana jest zgodnie z ideałami mikojanowskiego systemu żywienia zbiorowego:

W każdym domu mieściła się stołówka. Stoły poustawiano nie tylko wewnątrz sali, ale również na zewnątrz. Wszędzie widać było siedzących przy nich dziewczynki i chłopców. Jedni jedli obiad, pili herbatę, kawę czy oranżadę, inni czytali gazety, przeglądali czasopisma z obrazkami lub grali w loterię obrazkową, domino, szachy i warcaby. Przy każdej stołówce znajdowała się szafka, w której przechowywano podręczne gry ${ }^{24}$.

\footnotetext{
${ }^{21}$ Podporządkowanie wsi miastu miało swój początek w kolektywizacji lat 30. Założenia polityki bolszewików, traktującej wieś jako wewnętrzną kolonię, złagodniały od czasów Chruszczowa co do formy, natomiast ich esencja pozostała aktualna praktycznie do rozpadu ZSRR. Dopiero w epoce Breżniewa w literaturze radzieckiej pojawiła się afirmacja tradycyjnej kultury rosyjskiej wsi, wyrażona w tzw. prozie wiejskiej (dieriewienskaja proza), której przedstawicielami byli Fiodor Abramow, Wasilij Biełow, Walientin Rasputin, Siergiej Załygin, Władimir Tiendriakow i Wasilij Szukszyn. Patrz szerz.: Viola 2014, s. 27-47; Vanderheide 1980, s. 218-228.

${ }^{22}$ Nosow 1962, s. 47-48.

${ }^{23}$ Ibidem, s. 69. Lektura prasy codziennej dowodzi, że problem transportu miejskiego był jedną $\mathrm{z}$ bardziej dokuczliwych niedogodności życia codziennego w ZSRR. Poza niskiej jakości taborem, uciążliwa pozostawała jego niewystarczalność: autobusy, trolejbusy i tramwaje były notorycznie przeładowane.

${ }^{24}$ Ibidem, s. 50-51. Anastas Mikojan (1895-1978) był przez wiele lat ministrem przemysłu spożywczego i handlu. Jest uważany za twórcę nowoczesnego radzieckiego systemu żywienia zbiorowego. W myśl jego koncepcji na obszarze całego ZSRR powstawały przyzakładowe i miej-
} 
Stołówka staje się ośrodkiem rozrywki z typowymi radzieckimi atrakcjami: lektury, gry logiczne oraz aktywność sportowa. Korzystanie zeń przybiera formę kolektywną: nie ma mowy o indywidualnym czy rodzinnym wyjściu na obiad bądź mecz. Mieszkańcy Słonecznego Miasta, tak jak i samego ZSRR, czerpią z oferty miejskiej zawsze wespół $\mathrm{z}$ innymi. Uzupełnieniem usług gastronomicznych są kioski z wodą sodową ${ }^{25}$. Ponadto, mieszkania w Słonecznym Mieście zostały wyposażone $\mathrm{w}$ specjalne szafki ścienne $\mathrm{z}$ guzikami, przy których widniały napisy typu: „Zupa”, „Kasza”, „Kisiel”, „Kompot”, „Chleb”, i inne. Poprzez naciśnięcie wybranego guzika zamawia się dany posiłek ze stołówki. Rozwiązanie to miało służyć ograniczeniu do minimum konieczności gotowania w domu, co traktowano jako kulturowy przeżytek.

\begin{abstract}
Windy kuchenne dostarczały śniadań, obiadów i kolacji do mieszkań lokatorów bezpośrednio ze stołówek, znajdujących się na dole. Należy jednak dodać, że mieszkańcy Słonecznego Miasta rzadko korzystali z możliwości jedzenia $\mathrm{w}$ domu, bowiem woleli jeść w stołówkach, gdzie było o wiele weselej. Potrawy podawały tam dziewczynki i chłopcy, z którymi można było porozmawiać i pożartować ${ }^{26}$.
\end{abstract}

Najbardziej dobitnym potwierdzeniem tego, że w Słonecznym Mieście osiągnięto komunizm jako ostateczną fazę rozwoju społecznego, jest fakt eliminacji pieniądza.

Tutaj wszystko jest tak urządzone. Może pan wejść do każdej stołówki i zjeść, co pan zapragnie, a w każdym sklepie otrzyma pan każdą rzecz, która się panu spodoba, i to za darmo ${ }^{27}$.

- Jak się panu podoba nasze miasto? - zapytała Niteczka.

- Bardzo! - odrzekł Nieumiałek. - Macie tu rozmaite maszyny, kina i teatry, i tyle sklepów, a nawet stołówki...

- A czy w pana mieście nie jest tak jak u nas?

skie stołówki, bary i restauracje szybkiej obsługi, a przemysł spożywczy nastawiony był na masową produkcję szerokiej gamy produktów gotowych i półproduktów. Wszystko to miało służyć zwolnieniu kobiety radzieckiej $\mathrm{z}$ przygotowywania posiłków $\mathrm{w}$ warunkach domowych i tym samym zwiększeniu podaży siły roboczej. Patrz szerz.: Głuszczenko 2012.

${ }^{25}$ Nosow 1962, s. 71. W ZSRR w latach sześćdziesiątych i siedemdziesiątych XX wieku funkcjonowały automaty handlowe $\mathrm{z}$ wodą sodową, drobnymi przekąskami, kanapkami, gazetami, papierosami, a nawet przyborami biurowymi. Niektóre z nich były bardzo rozbudowane i pełniły funkcje „mini-sklepów”. Prawdopodobne, że kierownictwo partyjne dopuszczało myśl o całkowitej likwidacji handlu $\mathrm{z}$ obsługą. W przeciwieństwie jednak do bajkowej wizji Nosowa prawdziwe automaty działały wyłącznie na pieniądze. Patrz szerz.: Odnopozov 2016.

${ }^{26}$ Nosow 1962, s. 118. Kuchenna winda hiperbolizuje zjawisko odchodzenia od samodzielnego przygotowywania posiłków w domu. Plany w zakresie budownictwa mieszkaniowego w dużych miastach ZSRR z drugiej połowy l. sześćdziesiątych zakładały powstawanie kompleksów mieszkalnych $\mathrm{z}$ wielkiej płyty. Chodzi o połączenie dwóch lub trzech wieżowców wspólnym niskim budynkiem, w którym zlokalizowane byłyby rozmaite punkty usługowe, w tym przede wszystkim stołówki i kawiarnie. Pojawiła się też idea stołówki zlokalizowanej na każdym piętrze (sic!), podczas gdy w samym mieszkaniu znajdować się miał jedynie aneks kuchenny. Zob. np.: Kafanova 1965.

${ }^{27}$ Nosow 1962, s. 115. 
- Gdzie tam! - Nieumiałek machnął ręką. - Jakby komu u nas chciało się jabłka, to musiałby włazić na drzewo. Jak orzechów - to musiałby iść po nie do lasu. Bo u was sprawa jest prosta - idzie się do stołówki i je, czego dusza zapragnie, a u nas najpierw trzeba pracować, a dopiero potem się je.

- Ale przecież my także pracujemy - zaprotestowała Niteczka. - Jedni pracują w polu albo sadzie, inni robią rozmaite rzeczy w fabrykach, a później każdy bierze sobie w sklepach, to czego potrzebuje $e^{28}$.

O zaawansowaniu cywilizacyjnym Słonecznego Miasta świadczą także metody zapewniania porządku publicznego. W mieście funkcjonuje policja, jednak w praktyce jej rola sprowadza się do sterowania ruchem ulicznym oraz udzielania informacji komunikacyjnych. Jedyną stosowaną formą kary jest nagana.

Naruszających porządek było coraz mniej, tak że milicja zaczęła pomału zapominać, iż kiedyś istniały jakieś straszne kary, jak na przykład wsadzanie do aresztu. Słowo „areszt” zostało całkowicie wykreślone z pamięci i teraz nikt już nawet nie wiedział, co ono oznacza ${ }^{29}$.

W drugą część trylogii o Nieumiałku umiejętnie wpleciony został ciekawy wątek fantastyczno-naukowy. Bohaterowie stykają się z wynalazkami, które w epoce chruszczowowskiej odwilży stanowiły co najwyżej futurologiczne wizje. Po pierwsze, pojawia się system wirtualnej obsługi hotelowej:

Na tych drzwiach ukazał się nagle telewizyjny ekran, z którego spoglądała twarz dziewczynki o jasnych włosach i okrągłej rumianej buzi. Na jej uszach tkwiły słuchawki, a na stole stał mikrofon. Dziewczynka odezwała się z uprzejmym uśmiechem:

- Proszę podejść bliżej.

Cała trójka zbliżyła się nieśmiało.

- Państwo pragną zatrzymać się w hotelu? - zapytała dziewczynka i nie doczekawszy się odpowiedzi ciągnęła dalej: - Są wolne pokoje na piątym piętrze. Państwo będą łaskawi wejść tymi tylnymi drzwiami i wjechać na górę windą. Dziewczynka jeszcze raz się uśmiechnęła i znikła z ekranu. (...) Na piątym piętrze podróżni wyszli na korytarz i od razu ujrzeli na ścianie przed sobą ekran z uśmiechniętą twarzą znajomej dziewczynki.

- Numer państwa jest dziewięćdziesiąt sześć, na końcu korytarza po prawej stronie - przemówiła. - Ale przede wszystkim proszę każdego o wpisanie swego nazwiska do zeszytu, który leży na stole ${ }^{30}$.

Po drugie, bohaterowie poznają technologię monitoringu miejskiego:

Za drzwiami Nieumiałek w asyście milicjanta znalazł się w dużym jasnym pokoju. Ujrzał w nim jeszcze jednego milicjanta, który siedział na okrągłym obracającym się krześle przed rozrzędowym pulpitem, na którym widniały rozmaite wyłączniki, przełączniki, dźwignie, mikrofony, telefony oraz głośniki. Nad pulpitem rozmiesz-

\footnotetext{
${ }^{28}$ Ibidem, s. 131.

${ }^{29}$ Ibidem, s. 85.

${ }^{30}$ Ibidem, s. 53-54.
} 


\begin{abstract}
czono w czterech rzędach pięćdziesiąt dwa kuliste ekrany telewizyjne, w których niby w lustrach, odbijały się pięćdziesiąt dwa skrzyżowania ulic w mieście, a także sąsiadujące domy, jadące pojazdy, przechodnie i w ogóle wszystko, co może znajdować się na ulicy. Pośrodku pokoju wisiał jeszcze jeden taki kulisty ekran, tylko, że o wiele większych rozmiarów. (...). My tu w komisariacie widzimy wszystko. Proszę, podejdźcie bliżej, obywatelu. (...).

- Pod obserwacją naszego komisariatu znajdują się pięćdziesiąt dwa skrzyżowania ulic (...). - Wystarczy rzucić okiem na te pięćdziesiąt dwie kule, a można ujrzeć wszystko, co dzieje się na każdym skrzyżowaniu. Jeżeli źle widać szczegóły na małych ekranach, to włączamy większy ${ }^{31}$.
\end{abstract}

Po trzecie, wspomniane automatyczne taksówki z programatorami trasy przypominają nie tylko współczesną nawigację samochodową, ale i wciąż kontrowersyjne dziś autonomiczne samochody:

Czarodziej podszedł do ostatniej taksówki, wsunął rękę do szpary za radiatorem i wyjął tekturową tabliczkę, na której wydrukowana była mapa krainy ludków z bajki. Odszukał na mapie Kwiatowe Miasto, odłożył na miejsce, po czym odezwał się:

- Wsiadajcie teraz do auta, naciśnijcie guzik na tablicy rozdzielczej i jedźcie. Wóz sam zawiezie was, dokąd trzeba ${ }^{32}$.

Wreszcie, niektóre projekty z wykorzystaniem energii słonecznej nawet w drugiej dekadzie XXI wieku realizowane są jedynie częściowo:

- Czy dachy w waszym mieście zrobione są z rybiej łuski? - zapytał Nieumialek.

- Nie - odparł Klepka. - To, co panu wydaje się rybią łuską, to baterie słoneczne ustawione na dachach budynków. W tych bateriach energia słoneczna zamienia się w energię elektryczną, która gromadząc się w specjalnych akumulatorach, służy potem do oświetlenia i ogrzania mieszkań, wprawia w ruch windy, ruchome schody i różne motory ${ }^{33}$.

Elementy fantastyki naukowej dawały pisarzom radzieckim zakamuflowany sposób na mówienie o wynaturzeniach systemu. W analizowanej powieści mogłyby to być: inwigilacja, totalna mechanizacja, dążenie do pełnego podporządkowania natury człowiekowi.

Wysoki standard życia pozwala dorosłemu czytelnikowi potraktować Słoneczne Miasto jako bajkową witrynę osiągnięć socjalizmu. Atrakcje, jakie spotykają tam Nieumiałka, przywodzą na myśl strukturę radzieckiego reportażu prasowego, gdzie o reprezentatywności miasta świadczy stopień jego uprzemysłowienia, a głównym punktem zwiedzania jest obiekt przemysłowy (fabryka, nowoczesne punkty usługowe, rozwiązania architektoniczne lub transportowe). Przedsiębiorstwa są poznawane „od środka”: wraz z infra-

${ }^{31}$ Ibidem, s. 82.

${ }^{32}$ Ibidem, s. 183. Samochód autonomiczny budzi dziś wciąż kontrowersje ze względów psychologicznych, prawnych i moralnych, szczególnie po pierwszym wypadku śmiertelnym z udziałem takiego samochodu, do którego doszło w Arizonie w USA w marcu 2018.

${ }^{33}$ Ibidem, s. 109. 
strukturą przyzakładową (sklepy pracownicze, transport, zakwaterowanie robotników, sprawy socjalne). Ewentualne walory historyczne miejscowości (zabytki, ruiny, muzea) albo nie pojawiają się w narracji, albo pozostają $\mathrm{w}$ tle, w charakterze lokalnego folkloru. Gospodarze zwiedzanej miejscowości są zawsze bardzo gościnni i z cierpliwością godną starszego brata dzielą się swoją wiedzą i doświadczeniami. W klimacie czerpania $\mathrm{z}$ wiedzy i doświadczeń „starszych braci” przebiega wizyta Nieumiałka w wytwórni mebli, fabryce telewizorów i radioodbiorników oraz w fabryce odzieży. Planowane są także odwiedziny Miasteczka Nauki (czegoś w rodzaju kampusu badawczego) i zapoznanie się z efektami pracy uczonych Malwy (profesorki kosmografii) i Rybki (inżynierki budującej rakietę do lotu na Księżyc). Ostatecznie bohaterowie nie trafiają do Miasteczka Nauki, ale dyskretnie napomknięty wątek eksploracji kosmosu zdradza przedsmak ostatniej części trylogii.

\section{DAWILON, PANOPTIKUM, LAS KABANOS I INNE ZŁE MIEJSCA - AMERYKAŃSKIE PIEKŁO W ZWIERCIADLE KSIĘŻYCA}

Część trzecią „Nieumiałek na Księżycu” opublikowano w momencie, w którym ZSRR miał już na koncie ogromne sukcesy: wystrzelono pierwszego sztucznego satelitę Ziemi, odbyły się udane loty kosmiczne Jurija Gagarina i Walentyny Tiereszkowej, Aleksiej Leonow wyszedł w otwarty kosmos. Cała radziecka astronautyka i przemysł kosmiczny żyły przygotowaniem do lądowania człowieka na Księżycu, a podbój kosmosu stał się lejtmotywem radzieckiej kultury popularnej lat sześćdziesiątych ${ }^{34}$. Clou narracji ostatniej części dotyczy jednak nie samej rywalizacji mocarstw o panowanie w przestrzeni kosmicznej, ale szerzej: rywalizacji systemów-światów, w której kapitalizm zostaje ostatecznie pokonany.

Kontakty z mieszkańcami Słonecznego Miasta owocują wspólną wyprawą Umiałka, Rybki i Malwy na Księżyc. Po ich powrocie, wśród karzełków zapanowuje "kosmiczna gorączka”: w obu miastach kontynuowane są badania kosmiczne, aktywnie popularyzowana jest wiedza o kosmosie, zbudowano Kosmiczne Miasteczko - ośrodek badawczy, w którym powstała rakieta do wielozałogowego lotu w na Księżyc. Planowana ekspedycja ma potwierdzić hipotezę Umiałka, w myśl której pod widoczną powierzchnią Księżyca znajduje się jeszcze jedna kula zamieszkiwana przez księżycowe karzełki. W wy-

\footnotetext{
${ }^{34}$ Szerzej patrz: Gerovitch 2015, s. 1-26, 128-154; Etty 2015, s. 89-115.
} 
niku splotu nieprzewidzianych okoliczności na Srebrny Glob trafiają jedynie Nieumiałek i Pączek. Ich pobyt potwierdza przypuszczenia dotyczące znajdującego się tam życia, w sensie fizycznym jest ono nawet bardzo podobne do ziemskiego: księżycowe karzełki wyglądają tak samo, jedzą mniej więcej to samo, tak samo mieszkają i lubują się w tych samych rozrywkach co na Ziemi. Skrajnie odmienna okazuje się natomiast organizacja stosunków społecznych.

Przedstawione przez Nosowa komponenty księżycowej rzeczywistości można podzielić na dwie grupy. Pierwsza dotyczy funkcjonowania jednostki w warunkach leseferystycznego (mocno zdeprawowanego) kapitalizmu. W mieście Dawilon - skojarzenie z biblijnym Babilonem, symbolem zepsucia i nierówności społecznych, nie jest przypadkowe - Nieumiałek po raz pierwszy styka się z pojęciem własności prywatnej. Nieświadomy konsekwencji, zrywa maliny z krzaka rosnącego na prywatnej posesji lokalnego oligarchy Klopsa.

- Maliny były twoje? Odpowiadaj!

- Dlaczego nie moje? - odpowiedział Nieumiałek. - Przecież nikomu nie zabierałem. Sam zerwałem z krzaka. (...).

- Już ty mnie popamiętasz! (...). - Nie widziałeś, że tu jest własność prywatna?

- Jaka własność prywatna?

- Ty co, nie uznajesz własności prywatnej? - spytał podejrzliwie Klops.

- Dlaczego nie uznaję? - zasmucił się Nieumiałek. - Uznaję, tylko nie wiem co to znaczy! U nas nie ma żadnej prywatnej własności. My wszystko siejemy razem i drzewa też sadzimy razem, a potem każdy bierze to, co jest mu potrzebne ${ }^{35}$.

W dalszej kolejności okazuje się, że praktykowane jest wymierzanie kary na własną rękę, szczególnie wtedy, kiedy nie ma się układów z policją:

- Twoje szczęście, że jestem dobrym karzełkiem, - powiedział Klops do Nieumiałka. - Nie oddam cię policji. Policji, bracie, lepiej nie zawiadamiać. Z tego żadnego pożytku nie będzie, czort z nią! ${ }^{36}$

Za podjadanie malin Klops poszczuł Nieumiałka psami. Próbował go też zastrzelić, bo jak się okazuje, broń w prywatnych rękach jest na Księżycu na porządku dziennym, podobnie jak obecność struktur mafijnych czy bestialstwo funkcjonariuszy policji, którzy na każdym kroku sięgają po paralizatory. Kontrast pomiędzy brutalnością tej rzeczywistości a ładem i swego rodzaju łagodnością Słonecznego Miasta jest uderzający nawet dla dorosłego czytelnika.

\footnotetext{
${ }^{35}$ Nosov 1988, s. 114.

${ }^{36}$ Ibidem, s. 115.
} 
Największy szok wywołuje u Nieumiałka zjawisko pieniądza, o istnieniu którego boleśnie przekonuje się w restauracji. Za zjedzenie obiadu bez płacenia Nieumiałek trafia do aresztu (jak pamiętamy, ta forma kary została już wyeliminowana w Słonecznym Mieście), wcześniej jednak policjant proponuje mu wykupienie się za łapówkę. Konieczność posiadania pieniędzy jest warunkiem sine qua non funkcjonowania na Księżycu, stąd zdobywanie środków na najbardziej podstawowe potrzeby - jedzenie i nocleg staje się codziennym wyzwaniem Nieumiałka. Szybko przekonuje się, że opłaty wymaga się również za opiekę medyczną oraz, że chorzy i niepełnosprawni, tj. niezdolni do pracy, są całkowicie pozbawieni ochrony ze strony państwa i tym samym skazani na wegetację. Godziwe życie wiedzie tylko klasa posiadająca. Robotnicy są słabo opłacani i praktycznie pozbawieni praw, ale widmo bezrobocia, oznaczającego już zupełną degrengoladę, skutecznie tłumi w nich wszelkie zapędy do buntu. Nie ma instytucji wspierających pracę inteligencji. Miejscowi astronomowie znają budowę Księżyca, jednak żaden z milionerów nie zainteresował się finansowaniem ekspedycji badawczej na zewnętrzną powłokę planety. I wreszcie cały sektor usług dostępnych na Księżycu nastawiony jest na wyciągnięcie z klienta jak największych pieniędzy, bez dbałości o zapewnienie jakości usług na adekwatnym poziomie.

Satyra na kapitalizm zawiera się też w historii Pączka, któremu po wylądowaniu na Księżycu udaje się z sukcesem rozkręcić mały biznes. W krótkim czasie jednoosobowa firma zajmująca się wydobyciem i dystrybucją soli przekształca się w prężną korporację, a sam Pączek nie tylko nie musi pracować fizycznie, ale nawet obowiązki zarządcze deleguje na wykwalifikowaną kadrę. Czerpanie zysków i możliwość oddawania się przyjemnościom nie trwają jednak długo. Korporacja Pączka zostaje wyeliminowana przez konkurencję, oszczędności topnieją w zastraszającym tempie i ostatecznie Pączek zatrudnia się jako siła pociągowa na diabelskim młynie. Nie sposób pozbyć się wrażenia, że wątek ten służy zdyskredytowaniu jednego z najpopularniejszych mitów społecznych fundujących amerykańską tożsamość zbiorową: „od pucybuta do milionera”.

Druga grupa komponentów księżycowej rzeczywistości w sposób parodystyczny przedstawia instytucje i praktyki kapitalizmu. Za namową lokalnych mafiosów Nieumiałek zakłada spółkę akcyjną „Towarzystwo Roślin-Gigantów”, w planach której zysk ze sprzedaży akcji ma być przeznaczony na budowę statku kosmicznego, umożliwiającego dotarcie do zewnętrznej powłoki Księżyca. Tam bowiem została rakieta, którą Nieumiałek przyleciał z Ziemi, 
a w niej nasiona owoców i warzyw uprawianych w Kwiatowym Mieście ${ }^{37}$. Szybko okazuje się jednak, że prowadzenie prosperującej działalności gospodarczej jest możliwe jedynie z pozycji kapitalisty lub gangstera. Większość branż została zmonopolizowana, najwięksi przedsiębiorcy uczestniczą w zmowie kartelowej, nieliczne związki zawodowe działają w podziemiu, powszechne są różne metody zastraszania konkurencji, łapówkarstwo i szemrane kontakty. $\mathrm{Na}$ Księżycu pracuje giełda papierów wartościowych, w przestrzeni publicznej obecna jest nachalna reklama, a kapitaliści poprzez cenzurowanie prasy sterują obiegiem informacji. Ostentacyjna konsumpcja uprawiana przez bogaczy i pożądana przez biedotę, której służą lichwiarskie oferty banków oraz sprzedaż ratalna, ma dowodzić społecznego zepsucia. Ad extremum, kulminacją hedonizmu materialistycznego, niezrozumiałego dla radzieckiego człowieka pracy, jest zawód psiej niani ${ }^{38}$.

Dramatyczne przygody Nieumiałka na Księżycu wieńczy jednak triumfalne zakończenie. Z Ziemi przybywają przyjaciele, którzy nie tylko wyciągają go z tarapatów, ale także pomagają miejscowemu proletariatowi w dziele rewolucji. Na Srebrnym Globie zmienia się porządek społeczny: robotnicy przejmują fabryki, kapitaliści zostają zmuszeni do pracy, a zgromadzony przez nich kapitał podlega nacjonalizacji z przeznaczeniem na rozbudowę publicznej infrastruktury. Seria zmian rozpoczyna się od porwania statku, którym policja wywozi bezdomnych na odległą wyspę, gdzie z czasem przemieniają się w osły. Motyw statku można interpretować jako odwołanie do krążownika „Aurora”, z którym związana jest symbolika początku bolszewickiej rewolucji październikowej oraz do pancernika „Potiomkin” - słynnego zbuntowanego okrętu z 1905 roku. Ostatecznie Nieumiałek wraz z przyjaciółmi wraca szczęśliwie na Ziemię. Ich wyprawa odnosi podwójny sukces: po pierwsze dostarcza empirycznych dowodów na potwierdzenie lansowanej w Kwiatowym Mieście tezy o budowie Księżyca, po drugie - co bardziej znaczące - zwycięża nad kapitalizmem.

\footnotetext{
${ }^{37}$ Motyw nasion przywiezionych na Księżyc w darze z innej planety to odwołanie to radzieckiej strategii promowania związkowej produkcji na zewnątrz kraju. Szczególnie, że - jak zauważył Nieumiałek - „pomidory i ogórki na Księżycu były kilkadziesiąt razy mniejsze niż te, do których przywykł na Ziemi”. Ibidem, s. 112. Autoreklama ziemskich (czytaj: radzieckich) płodów rolnych została dodatkowo wzmocniona poprzez porównanie do ich księżycowych (czytaj: amerykańskich) odpowiedników.

${ }^{38}$ Stosunek do zwierząt, który obejmuje nietradycyjną pielęgnację (fryzjer, SPA, ubiór, zoopsycholog), był wyśmiewany także w kulturze popularnej PRL-u. Można tu przywołać Pusię - pieska z filmu „Kogel-mogel” karmionego cielęciną, lub zdziwienie Pawlaka i Kargula w filmie „Kochaj albo rzuć", kiedy w czasie pobytu w USA zobaczyli psi cmentarz.
} 


\section{NIEUMIAŁEK ĆWIERĆ WIEKU PO UPADKU ZSRR}

O popularności trylogii świadczą liczne wznowienia wydawnicze, adaptacje filmowe (w tym liczba wyświetleń tych filmów w serwisie Youtube) oraz wątki dotyczące powieści na forach poświęconych kulturze radzieckiej ${ }^{39}$. Lektura publikowanych tam treści przekonuje, że cykl powieści Nosowa istotnie stwarza możliwość podwójnego odczytania ${ }^{40}$. O ile uwaga najmłodszego czytelnika pozostanie skupiona na dynamice akcji, o tyle dorosły doceni - paralelnie czy to po latach - realia świata przedstawionego rozpiętego pomiędzy utopią i antyutopią ${ }^{41}$.

${ }^{39}$ Pierwsza i druga część powieści zostały zekranizowane jeszcze w ZSRR, odpowiednio w l. 1971-1973 i 1976-1977 (jako filmy kukiełkowe). Ekranizacja trzeciej części powstała już w Rosji w 1. 1997-1999 w prywatnym studiu filmowym „Fabrika animacionnogo fil'ma”. Filmowa wersja „Nieumiałka na Księżycu” została dość mocno skorygowana pod kątem poprawności politycznej: np. napięcia społeczne wywołuje nie kapitalizm jako taki, ale jego dalekie pokłosie: konflikt ekologiczny powodowany przez zanieczyszczenia chemiczne z zakładów przemysłowych.

${ }^{40} \mathrm{~W}$ tym kontekście, historyk literatury Sergej Dmitrenko przywołuje również inne utwory Nosowa. „Tuk, tuk, tuk” - z pozoru banalna historia o uczestnikach obozu pionierskiego, którzy spędzili bezsenną noc z powodu stukania wron o dach, przez współczesnych odczytywana była jako aluzja do nocnych aresztowań dokonywanych przez funkcjonariuszy NKWD. Nie bez znaczenia jest fakt, że samochód do przewożenia aresztantów nazywano „czornyj woron”. „Ogórki” - opowieść o chłopcu, który ukradł z kołchozowego pola kilka ogórków, Dmitrenko proponuje odczytywać na tle opublikowanego w 1932 roku dekretu „O ochronie mienia przedsiębiorstw państwowych, kołchozów, spółdzielni oraz wzmocnieniu własności społecznej”, potocznie nazywanego „prawem pięciu kłosów” oraz Postanowienia Rady Komisarzy Ludowych z 1935 roku o „O sposobach walki z przestępczością wśród niepełnoletnich”, na mocy którego do odpowiedzialności karnej pociągano dzieci od 12 roku życia. Zob. Sudilowskij 2000.

${ }^{41}$ Korzenie radzieckich utopii literackich sięgają jeszcze okresu przedrewolucyjnego. W pierwszej kolejności należałoby wymienić powieść „Co robić?: o nowych ludziach” Mikołaja Czernyszewskiego (1863) - z wizją szklanych domów i nowych ludzi zapowiadających odrodzone, idealne społeczeństwo przyszłości. Następnie „Czerwoną Gwiazdę” Aleksandra Bogdanowa (1908), gdzie pod postacią utopijnego społeczeństwa Marsjan odnajdzie czytelnik wyobrażenie socjalistycznej wspólnoty. Cechują ją powszechny egalitaryzm, pełna harmonia jednostki i społeczeństwa (skutkująca osłabieniem poziomych więzi rodzinnych, co stanowiło istotny składnik późniejszej radzieckiej ideologii wychowawczej), możliwość zaspokajania wszystkich potrzeb i odnajdywanie źródła przyjemności w pracy. Warta uwagi jest także powieść Konstantina Mereżkowskiego „Raj na Ziemi albo Sen nocy zimowej. Baśń-utopia z XXVII w.” (1903) przedstawiającą utopię o charakterze eugeniczno-rasistowskim osiągniętą metodami socjotechnicznymi, na takiej samej zasadzie, na jakiej nadaje się kształt tworzywu. Porewolucyjni autorzy utopii to m.in.: Aleksiej Tołstoj, Wywian Itin, Jakow Okuniew, Aleksiej Bielajew, Jan Łarri czy Iwan Jefriemow. Ciekawe jest także, zauważalne w II poł. XX wieku, zjawisko ewolucji od utopijnych wizji ogólnoświatowego komunizmu do antyutopistycznego zwątpienia $\mathrm{w}$ ten model ustroju, które przejawia się $\mathrm{w}$ twórczości Arkadija i Borysa Strugackich. Do pierwszego nurtu należą takie powieści tych autorów jak: „Powrót” (1960) i „Daleka Tęcza” (1963), do drugiego natomiast: „Zachłanne rzeczy wieku” (1965). Bez wątpienia, najsłynniejszą antyutopią wydaną w Rosji Radzieckiej jest powieść Jewgienija Zamiatina „My” (1921), przerażająca wizja, z pozoru idealnego, Państwa Jedynego, w którym życie toczy się według Dekalogu Godzin. Poszczególne jednostki mają zapewnione dosłownie 
Posługiwanie się utopizmem i antyutopizmem wymagało od pisarzy radzieckich niebywałego kunsztu. W 1934 roku na I Zjeździe Pisarzy Radzieckich zdefiniowano doktrynę realizmu socjalistycznego, która dopuszczała, czy wręcz nawoływała do tworzenia utopii literackich, ale w ściśle określonej formie. Chodziło o to, by:

(...) przedstawiać to, co powinno istnieć w przyszłości według założeń ideologii komunistycznej jako rzeczywistość już zrealizowaną ${ }^{42}$.

Właśnie coś takiego osiąga Nosow, tworząc Słoneczne Miasto. Opisane tam „realia”, ściśle spójne z obietnicą propagandy, mają przekonywać, tak jak Chruszczow trakcie XXII Zjazdu KPZR w październiku 1961 roku: oto bajkowy komunizm jest niemal w zasięgu ręki ${ }^{43}$. Jednocześnie Nosow przemyca elementy krytyki otaczającej rzeczywistości, dzięki czemu wypracowuje sobie status autora, który potrafił tworzyć inteligentną literaturę w skomplikowanych czasach.

Pomimo iż formalnie utopia i antyutopia rozgrywają się najczęściej w przyszłości, czasem w przeszłości, w nieznanych krajach bądź poza granicami ziemi, opisane w nich sytuacje wyrastały zawsze z krytyki stosunków istniejących w czasie i kraju autora $^{44}$.

Współczesna recepcja trylogii o Nieumiałku jest bardzo popularnym wątkiem nostalgicznego dyskursu o ZSRR. Poza ogólnym sentymentem (dla większości wychowanych w poststalinowskim ZSRR Nieumiałek, obok Czeburaszki i lodów Eskimo, pozostaje niezbywalnym elementem pozytywnych wspomnień $\mathrm{z}$ dzieciństwa) warto przywołać dwa najczęściej powtarzające się motywy. Po pierwsze, wyraźnie zarysowany kontrast pomiędzy życiem karzełków w Słonecznym Mieście a tym, które wiodą karzełki na Księżycu, w dziecięcym odczytaniu wypadał na korzyść tych ostatnich. Słoneczne Miasto jawiło się jako śmiertelnie nudne, a Nieumiałek, będąc bohaterem najbardziej podobnym do normalnego dziecka, po prostu do niego nie pasował. Refleksja dorosłych obnaża jeszcze jeden fakt: Słoneczne Miasto mimo doskonałości organizacyjnej okazało się całkowicie pozbawione mechanizmów samoobrony. Kiedy Nieumiałek nieumyślnie zamienił trzy przypadkowe osły w ludzi, a te wprowadziły do miasta plagę chuligaństwa - nikt nie mógł jej

wszystko: jedzenie, odzież, mieszkanie, pracę, czas na odpoczynek, na sen i seks, ale żadna z tych rzeczy nie jest przedmiotem ich wolnego wyboru. Zob. Brzóstowicz-Klajn 2012, s. 155-186. Por. Serbinenko 1989, s. 242-255. Patrz też: Duda 1995.

${ }^{42}$ Gildner, s. 31.

${ }^{43}$ Patrz szerz.: Vajl' i Genis 2013, s. 21-31.

${ }^{44}$ Gildner 1997, s. 27. 
skutecznie zwalczyć. Mieszkańcy podejmowali różne próby jednostkowej obrony, ale ostatecznym ratunkiem okazało się nie - jak można byłoby przypuszczać - rozwiązanie systemowe, tylko interwencja czarodzieja, tj. siły nadprzyrodzonej $j^{45}$.

Rzeczywistość Księżyca - przeciwnie - mimo swojej nieprzewidywalności i brutalności wyzywała, oprócz oczywiście strachu i współczucia u młodszych, co najmniej zaciekawienie u starszych. Dowodzi to, że mimo wysiłku oficjeli partyjnych nigdy nie udało się wyeliminować powszechnego w ZSRR zainteresowania Ameryką ${ }^{46}$. Z drugiej strony, współcześnie w interpretacji dorosłych znacznie częściej powtarza się porównanie Księżyca do dzisiejszej Rosji, aniżeli Stanów Zjednoczonych II poł. XX wieku. W marcu 2017 roku 33-letni bloger z Krasnodaru Michaił Małachow opublikował na portalu społecznościowym „VKontakte” fragment z „Nieumiałka na Księżycu” opatrzony ilustracją Gienricha Walka. Był to fragment, w którym Kłosek - przedstawiciel księżycowego proletariatu, tłumaczy przybyłej z Ziemi astronautce Rybce, jaką rolę na Księżycu spełnia policja:

\begin{abstract}
- To bandyci! - z rozdrażnieniem powiedział Kłosek. Słowo honoru, bandyci! Powinni chronić ludzi przed złodziejami, a naprawdę chronią tylko bogaczy. A ci bogacze to najwięksi złodzieje. Okradają nas, zasłaniając się prawem, które sami tworzą. A powiedzcie, jaka to dla mnie różnica: okradają mnie zgodnie $\mathrm{z}$ prawem czy nie? Mnie przecież wszystko jedno! ${ }^{47}$
\end{abstract}

Małachow to były zwolennik reżimowej polityki Putina, parający się niegdyś płatną publicystyką w grupie prokremlowskiego blogera Borisa Rożyna (Colonela Cassada) na rzecz projektu politycznego „Noworosji”. W ciągu ostatnich kilku lat jego poglądy uległy radykalnej zmianie - dziś utożsamia się z rosyjską opozycją skupioną wokół Aleksieja Nawalnego. W październiku 2017 odebrał dziwny telefon $\mathrm{z}$ wezwaniem na przesłuchanie $\mathrm{w}$ związku m.in. $\mathrm{z}$ zarzutem "rozsiewania nienawiści wobec funkcjonariuszy policji” ${ }^{48}$. W ponad pół wieku po publikacji „Nieumiałka na Księżycu” ilustrowane tam przepaść majątkowa, nierówność wobec prawa, sprzedajność i przemoc policji, mające szkalować Amerykę, dobitnie asocjują się z codziennością rosyjskiego dzikiego kapitalizmu.

\footnotetext{
${ }^{45}$ Zob. Vajl' 2011.

${ }^{46}$ Ball 2003, s. xiii.

${ }^{47}$ Nosov 1988, s. 402.

${ }^{48}$ Krutov 2017.
} 


\section{BETWEEN THE UTOPIA OF SOCIALISM AND THE CARICATURE OF THE WEST. A NON-CHILDREN'SINTERPRETATION OF THE WORLD DEPICTED IN THE NIKOLAI NOSOV'S “DUNNO” TRILOGY}

\section{Summary}

The paper is devoted to the trilogy written by Nikolai Nosov in 1953-1965, comprising The Adventures of Dunno and his Friends, Dunno in Sun City and Dunno on the Moon all of which rank high in the canon of Soviet literature for children. The first part introduces the ideological and educational objectives that literature for children in the USSR was expected to pursue, as well as the writer himself. The author argues that Nosov's novels, officially intended for children, offer broad interpretive possibilities for the adult reader as well. Subsequent parts provide an analysis of the instalments of the trilogy whilst focusing on the setting in which the story takes place. This approach reveals satirical references to the Soviet and American realities of the 1950s and 1960s. In the final part, the conclusions are confronted with the contemporary perceptions of the novel, drawing on the content posted online.

\section{Bibliografia}

Amsterdamski S. 1981, Życie naukowe a monopol władzy (casus Łysenko), Warszawa.

Ball A.M. 2003, Imagining America: influence and images in twentieth-century Russia, Lanham.

Biografiâ Nikolaâ Nosova. 23.11.2013 [online]. Ria Novosti. Rossiâ segodnâ [dostęp: 2018-03-02]. Dostępny w Internecie: <https://ria.ru/spravka/20131123/978957074.html>.

Brzóstowicz-Klajn M. 2012, Tomasz Morus w mundurku pioniera, czyli utopia i utopijność w polskim socrealizmie, Poznań.

Chłopek M. 2005, Bikiniarze. Pierwsza polska subkultura, Warszawa.

Cjurpa E. 1957, O wielkiej literaturze dla małych dzieci, Literatura Radziecka, 4, s. 116-122.

Delwig A. 2011, Life in Moscow. Communism and now, bmw.

Dom novogo byta 1966, Ogonëk, 2, s. 26-27.

Duda K. 1995, Antyutopia w literaturze rosyjskiej XX wieku, Kraków.

Etty J. 2015, Comic cosmonaut: space exploration and visual satire in Krokodil in the Thaw [w:] V. Strukov, H. Goscilo (red.), Russian Aviation, Space Flight, and Visual Culture, Abingdon-New York, s. 89-115.

Gerovitch S. 2015, Soviet Space Mythologies. Public Images, Private Memories, and the Making of a Cultural Identity, Pittsburgh.

Gildner A. 1997, Myśl utopijna w literaturze rosyjskiej, [w:] K. Galon-Kurkowa, T. Klimowicz (red.), Wielkie tematy kultury w literaturach słowiańskich, Wrocław, s. 26-32.

Głuszczenko I. 2012, Sowiety od kuchni. Mikojan i radziecka gastronomia, przekł. M. Przybylski, Warszawa.

Gould S. J. 1999, Niewczesny pogrzeb Darwina, przekł. N. Kancewicz-Hoffmann, Warszawa.

Kafanova L. 1965, Zavtra, Ogonëk, 24, s. 1-2.

Kazûl'kina I. 2001, Nikolaj Nikolajewič Nosov [online]. Knigi i deti. Bibliogid [dostęp: 2018-03-02]. Dostępny w Internecie: <http://bibliogid.ru/pisateli/o-pisatelyakh/483-nosovnikolaj-nikolaevich>. 
Köhler P. (red.). 2013, Studia nad łysenkizmem w polskiej biologii, Kraków.

Kozlov V. 2015, Stilâgi. Molodye, smelye, svobodnye, Sankt-Peterburg.

Krutov M. 2017. Neznajka i drugie ekstremisty [online]. Radio Svoboda [dostęp: 2018-03-05].

Dostępny w Internecie: <https://www.svoboda.org/a/28784731.html >.

Marszak S. 1952, Literatura - szkole, Literatura Radziecka, 9, s. 134-140.

Marszak S. 1958, O książce poznawczej dla dzieci, Literatura Radziecka, 4, s. 169-173.

Nosov N. 1988, Neznajka na lune, Kiev.

Nosow M. 1962, Nieumiałek w Słonecznym Mieście, przekł. J. Lewandowska, Warszawa.

Nosow M. 1984, Przygody Nieumiałka i jego przyjaciól, Moskwa.

O'Mahony M. 2017, Ever onwards, ever upwards? Representing the aviation hero in Soviet art [w:] V. Strukov, H. Goscilo (red.), Russian Aviation, Space Flight, and Visual Culture, Abingdon-New York, s. 35-52.

Odnopozov I. 2016, Torgovye avtomaty. Kievskie avtomatcziki, Kiev.

Pagaczewski S. 1965, Porwanie Baltazara Gąbki, Warszawa.

Pisarz z Krainy Deszczowców - rozmowa Katarzyny Szczerbowskiej z Grzegorzem Leszczyńskim, literaturoznawcą, badaczem literatury dla dzieci i młodzieży, 10.07.2016 [online]. Rzeczpospolita, [dostęp: 21.09.2018]. Dostępny w Internecie: <https://www.rp.pl/PlusMinus/307079929-Leszczynski-Pisarz-z-Krainy-Deszczowcow.html>.

Radziwinowicz W. 2017, Dzień Zwycięstwa po moskiewsku. Awiację Rosji pokonała pogoda, najgorsza od 1922 roku [online]. Wyborcza.pl [dostęp: 15.01.2018]. Dostępny w Internecie: $<$ http://wyborcza.pl/7,75399,21784496,dzien-zwyciestwa-po-moskiewsku-awiacje-rosjipokonala-pogoda.html>.

Schier W. 1982, Wielkie pionierskie przeloty lotnicze. Samoloty w historii i miniaturze, Warszawa.

Serbinenko V. 1989, Tri veka skitanij v mire utopii. Čitaâ brat'ev Strugackih, Novyj mir, 5, s. 242-255.

Sudilowskij A. (reż.). 2000, Pisateli naševo detstwa. He tolko o Neznajke. Nikolaj Nosov [online]. Rossiâ K [dostęp: 2018-03-02]. Dostępny w Internecie: <http://tvkultura.ru/video/ show/brand_id/32799/episode_id/691738/>.

Tveritina A. 2014, Soviet children's literature: The struggle between ideology and creativity [online]. Russia Beyond [dostęp: 2018-03-03]. Dostępny w Internecie: <https://www.rbth. com/literature/2014/06/27/soviet_childrens_literature_the_struggle_between_ideology_and _creativity_3776>.

Vajl' P. 2011, Neznajka [online]. Radio Svoboda [dostęp: 2018-03-05]. Dostępny w Internecie: <https://www.svoboda.org/a/24204541.html>.

Vajl' P., Genis A. 2013, 60-e. Mir sovetskogo čeloveka, Moskva.

Vanderheide D. 1980, Ethnic Significance of the Non-Black Earth Renovation Project, [w:] E. Allworth (red.), Ethnic Russia in the USSR. The Dilemma of Dominance, New York, s. $218-228$.

Viola L. 2014, Imperium Stalina. Gułag i policyjna kolonizacja w Związku Sowieckim w latach trzydziestych, [w:] T. Snyder, R. Brandon (red.), Stalin i Europa. 1928-1953, przekł. S. Kędzierski, Poznań, s. 27-47.

Voskobojnikov V. 2012, Detskaâ literatura včera i segodnâ. A zavtra?, Voprosy literatury, 5, s. 76-88.

Zaloga S.J. 2003, Berety z gwiazdami. Radzieckie wojska powietrznodesantowe, przekł. J. Skowroński, Warszawa. 